\title{
İnsan Protein Etkileşim Ağı Kullanarak Tiroid Karsinomu İle İlgili Moleküler Hedef ve Biyoişaretçi Adayların Belirlenmesi
}

\author{
Identification of Thyroid Carcinoma Related Molecular Targets and Signatures Using Human \\ Protein Interaction Network
}

\author{
Esra GöV (10) \\ Adana Alparslan Türkeş Bilim ve Teknoloji Üniversitesi, Biyomühendislik Bölümü, 01250, Adana, Türkiye
}

$\ddot{\mathbf{O z}}$

Tiroid kanseri görülme sıklığı yüksek olan ve ölümcül bir kanser türüdür. Dolayısıyla tiroid kanserinde etkin rol alan moleküllerin belirlenmesi hastalığın erken tanı ve tedavi stratejilerinin oluşturulması için çok önemlidir. Bu çalışmada yüksek boyutlu işlevsel genomiks verilerinin sistem biyolojisi araçları ile bütünleştirilerek analizi sonucu tiroid kanserine özgü moleküler hedefler ve biyoişaretçi adaylar belirlenmiştir. Zenginleştirme analizi sonucunda önemli kanser yolaklarının, metabolik yolakların ve immun sistem ilgili yolların aktifleştiği belirlenmiştir. İleri istatistiksel analizler ile belirlenen gen anlatımı farklılık gösteren genlerin protein etkileşim ağ oluşturulmuş ve tiroid kanserine özgü moleküler hedefler ve biyoişaretçi adaylar JUN, LRRK2, BCL2, CCND1, TLE1, MET, ICAM1, DDB2 ve RXRG olarak belirlenmiştir. Bağımsız bir veri setinin analizi ile, bu genlerin tümör ve normal dokuları ayırt edebileceği belirlenmiştir. Bu proteinler arasından JUN, TLE1 ve DBB2'nin yeni moleküler hedef ve biyoişaretçi aday olabileceği bulunmuştur. Belirlenen hedeflerin papiller tiroid kanserinin teşhis ve tedavi stratejilerinin oluşturulmasında kullanılabileceği öngörülmektedir. Ancak söz konusu adayların eş zamanlı PCR ile deneysel çalışmalarının yapılması gerekmektedir.

Anahtar kelimeler: Sistem biyotıbbı, istatiksel analiz, kanser, biyobelirteç

\begin{abstract}
Thyroid cancer is a fatal disease has a high incidence. Therefore, the determination of molecules involved in thyroid cancer is very crucial for early diagnosis and treatment strategies of the disease. In this study, high-dimensional functional genomic data were integrated with system biology tools and the molecular targets and signatures in thyroid cancer were determined. As a result of enrichment analysis, it was determined that important cancer pathways, metabolic pathways and immune system related pathways were activated. The protein - protein interaction network was reconstructed using differential gene expression is determined by advanced statistical analysis and the molecular targets and signatures in thyroid cancer were determined as JUN, LRRK2, BCL2, CCND1, TLE1, MET, ICAM1, DDB2 and RXRG. It was determined that these genes can differentiate tumor samples and normal thyroid tissues via independent data analysis. Among these proteins, JUN, TLE1 and DBB2 were found to be novel molecular targets. It is predicted that these molecular targets can be used in the diagnosis and treatment strategies of papillary thyroid cancer. However, it is necessary to perform experimental studies with real time-PCR.
\end{abstract}

Keywords: Sytems Biomedicine, statistical analysis, cancer, biomarker

\section{GİRIŞ}

Tiroid kanserleri dünyada sıklıkla görülen endokrin maliğnitedir ve bu tümorler farklı klinik ve histolojik özelliklere sahiptir. Tiroid bezinde kansere neden olabilecek hücreler foliküler, parafoliküler, bağ dokusu ve bağışıklık sistemi hücreleridir. Foliküler hücrelerden papiller tiroid karsinomu, folikuler tiroid karsinomu ve anaplastik tiroid karsinomu; parafolikuler hücrelerden medüller tiroid karsinomu; bağ dokusu hücrelerinden sarkomlar; bağışıklık sistemi hücrelerinden ise lenfoma gelişir [1]. Tiroid kanserlerinin \%90-95'i folikül hücrelerinden köken alır. Folikül hücrelerinden kaynaklanan tiroid kanserlerinin yaklaşık \%80’i papiller tiroid kanseridir (PTK). Dolayısıyla PTK en sık görülen tiroid kanseridir [2]. 
PTK genetik analizinde RET/PTC ve RAS-BRAF gibi tanı koydurucu ve hedefe yönelik tedavi ajanlarının geliştirilmesine yol gösterici pek çok mutasyon tespit edilmiştir. RET proto onkogeni, MAP kinaz yolağını aktive eder ve birçok büyüme faktörünün reseptöre bağlanmasından sorumludur. Bu mutasyon ve beliteçlerin üzerinde en çok çalışılan, en iyi bilineni BRAFV600E mutasyonudur [3,4]. Ayrıca tedavi için bu yolakları hedef alan tirozin kinaz inhibitörleri kısmen hastalık kontrolü sağlarken hastalığın teşhisine yönelik bilinenler kısıtlıdır. Bu yüzden tanı, prognoz ve tedavi için yol gösterici daha iyi hasta yönetimi sağlayacak yeni biyoişaretçi adaylara ihtiyaç vardır.

Yüksek giriş çıkışlı moleküler etkileşim verileri ve genomik veri setleri, bir hastalığa bağlı olan aday genlerin tüm genom, metilom, transkriptom, proteom ve metabolom düzeyinde değerlendirilmesi için etkin olarak kullanılabilir. $\mathrm{Bu}$ veriler biyolojik sistemi bir bütün içinde anlayabilmemiz için büyük bir potansiyel taşır. Tiroid kanserinin çoğul transkriptom analizlerinin bütüncül bakış açısı ile değerlendirilmesi ve hedef genlerinin işlevsel analizi hala nadirdir.

Literatürde bugüne kadar gerçekleştirilen PTK ile ilişkili RNA düzeyindeki Sistem Biyolojisi temelli çalışmaların geneli değerlendirildiğinde, transkriptomik düzeyindeki çalışmaların kısıtlı sayıda olduğu görülmektedir. Yüksek yoğunluklu sentetik oligonükleotid mikroarrayleri kullanılarak, normal ve kanserli örnekler karşılaştırılmış ve anlatımı artan ve azalan genler belirlenmiştir $[5,6]$. PTK'nin invazyon mekanizmasını anlamaya ilişkin gerçekleştirilen çalışmada çeşitli invazyon bölgeleri ve normal dokulardan örnekler alınarak, mikroçip ile anlatımı değişen genler araştııılmıştır [7]. Diğer az sayıdaki çalışmalarda ise; mutant sıçanlar kanser modeli olarak kullanılarak, anlatımı değişen gen ifadeleri belirlenmiştir $[8,9]$. Son zamanlarda yayınlanan birkaç makalede bu çalışmaya benzer yaklaşımlar kullanılmıştır. Zhao ve Li beş veri setinin INMEX denilen bir program ile meta analizini yapmışlar, sonuçta FN1 ve TRAF6 yı hub protein olarak sunmuşlardır [10]. Diğer makalede ise bir veri setinin analizi yapılarak C3, PPARG, PAX8, JUN and MMP9 hedef biyobelirteç olarak belirlenmiştir [11]. Bir diğer yakın zamanda gerçekleştirilen çalışmada dört veri setinin analizini yapılarak normalize merkezi ölçüm adında bir metod ile belirlenen anlatımı değişen genlerinin etkileşim ağı kurulmuştur [12]. Literatürde bulunan çalışmalar değerlendirildiğinde, bu çalışmada kullanılan dört veri setinin bir arada çalışıldığı ve protein etkileşim ağının oluşturulduğu bir çalışmaya rastlanmamıştır. Hastalığın oluşum ve seyrinde önemli olabilecek yeni gen adaylarının tespit edilmesi açısından bu çalışma literatüre katkı sağlayacaktır.
Bu makale de farklı populasyon gruplarından elde edilen 100 'ün üzerinde hastayı kapsayan yüksek sayıda veri setleri bütünleştirilmiştir. Tiroid dokusuna ait yüksek boyutlu işlevsel genomiks verilerin ileri istatiksel analizi gerçekleştirilerek elde edilen sonuçlar insan protein etkileşim ağ ile bütünleştirilmiştir. Her bir veri setinin zenginleştirme analizleri yapılarak hastalıkla ilgili yolaklar belirlenmiş; hedef moleküller ve biyoişaretçi adaylar belirlenmiştir. Analizlerde kullanılan veri setlerinden bağımsız bir veri seti ile belirlenen genlerin biyoişaretçi olabilme potansiyeli araştırılmıştır.

\section{MATERYAL VE YÖNTEM}

\subsection{Materyal}

PTK hastalarının transkriptom profilleri ile ilgili veri setleri (GSE35570, GSE29265, GSE3467, GSE6004) National Center for Biotechnology Information Gene Expression Omnibus (NCBI-GEO) [13] veri bankasından elde edildi (Tablo 1). Papiller tiroid kanserine ait tümör dokuları kanser örnekleri olarak seçilmiş ve normal doku grupları ise genellikle tümörün çevresinden alınan sağlıklı dokular seçilmiştir. Veri setleri içerisinde, GSE35550 de, direkt radyasyona maruz kalmış tiroid kanseri dokuları çalışmaya dahil edilmemiştir. Radyasyonun direkt etkisi incelenmediği için örneklemden çıkarılmıştır. Çernobil sonrası gelişen tiroid kanseri örnekleri ya da sporadik tiroid kanseri dokuları örneklem içerisinde yer almaktadır. Çünkü çalışmanın amacı tümör ve tümör çevresinde bulunan normal dokularının incelenmesidir. Dolayısıyla tümörün radyasyon sonucu oluştuğu veya sporadik tümör mü olduğu ile bilgiler bu çalışmada dikkate alınmamıştır. Toplamda 68 tümör dokusu ve 54 sağlıklı tiroid dokuları ile çalışma gerçekleştirilmiştir. Bu veri setleri Affymetrix İnsan Genomu U133 Plus 2 Array platformunda yapılmış deneylerin sonuçlarıdır. Dizin farklılığından oluşabilecek yanlışları azaltmak amacıyla aynı platformda gerçekleştirilen çalışmalar kullanılmıştır. Toplanan veri setlerinin içerdiği ham veriler, ön istatistik testleri ile aykırı değerler tespit edilerek ileri analize uygun formata getirilmiştir.

Tablo 1. Çalışmada kullanılan veri setleri

\begin{tabular}{lllll}
\hline $\begin{array}{l}\text { Veri set- } \\
\text { leri }\end{array}$ & Örnekler & $\begin{array}{l}\text { Örnek sa- } \\
\text { yısı }\end{array}$ & Array tipi & $\begin{array}{l}\text { Kay- } \\
\text { nak- } \\
\text { lar }\end{array}$ \\
\hline & $\begin{array}{l}\text { Radyasyona } \\
\text { uğramayan }\end{array}$ & $\begin{array}{l}32 \text { kanser } \\
\text { ve 21 nor- }\end{array}$ & $\begin{array}{l}\text { Affymetrix İnsan } \\
\text { Genomu U133-2.0 }\end{array}$ & {$[14]$} \\
GSE35570 & $\begin{array}{l}\text { PTC dokuları } \\
\text { ve normal ti- } \\
\text { maid diroid dokuları }\end{array}$ & $\begin{array}{l}\text { dokusu } \\
\text { Array }\end{array}$ & \\
\hline \multirow{2}{*}{ GSE29265 } & $\begin{array}{l}\text { PTC ve tumör } \\
\text { çevresinden } \\
\text { alınan normal } \\
\text { dokular }\end{array}$ & $\begin{array}{l}\text { 20 kanser } \\
\text { ve 20 nor- } \\
\text { mal doku }\end{array}$ & $\begin{array}{l}\text { Affymetrix İnsan } \\
\text { Genomu U133-2.0 }\end{array}$ & - \\
\hline
\end{tabular}




\begin{tabular}{|c|c|c|c|c|}
\hline GSE3467 & $\begin{array}{l}\text { PTC ve tumör } \\
\text { çevresinden } \\
\text { alınan normal } \\
\text { dokular }\end{array}$ & $\begin{array}{l}9 \text { kanser ve } \\
9 \text { normal } \\
\text { doku }\end{array}$ & $\begin{array}{l}\text { Affymetrix İnsan } \\
\text { Genomu U133-2.0 } \\
\text { Array }\end{array}$ & [15] \\
\hline GSE6004 & $\begin{array}{l}\text { PTC'nin mer- } \\
\text { kezinden al1- } \\
\text { nan dokular } \\
\text { ve tumör çev- } \\
\text { resinden alı- } \\
\text { nan normal } \\
\text { dokular }\end{array}$ & $\begin{array}{l}7 \text { kanser ve } \\
4 \text { normal } \\
\text { doku }\end{array}$ & $\begin{array}{l}\text { Affymetrix İnsan } \\
\text { Genomu U133-2.0 } \\
\text { Array }\end{array}$ & [16] \\
\hline
\end{tabular}

\subsection{Yöntem}

\subsubsection{Anlatımı farklılık gösteren genlerin belirlenmesi}

Anlatımı farklılık gösteren genlerin bulunması için her veri seti bağımsız olarak Bioconductor yazılım platformu altında yer alan "limma" metodu ile [17] istatistiksel olarak analiz edildi. Gen anlatımı değişiklik gösteren genler hesaplanmış p-değerlerine $(p<0,05)$ göre ve değişikliğin yönü (gen anlatımı artan/azalan) ve kat değişimlerine (FC) göre hesaplandi. Gen anlatım düzeyi artan genler $\mathrm{FC}>2$, azalan genler $\mathrm{FC}<0,5$ olarak alınd.

\subsubsection{Biyolojik proses ve yolaklarm belirlenmesi}

Anlatımı değişen genlerin hangi biyolojik proses ve yolaklarda yer aldığını belirlemek için zenginleştirme analizleri yapıldı. Bu analizler için DAVID [18] programı kullanıldı. $\mathrm{P}$ değeri 0,05 den küçük olan terimler belirlendi ve sonuçlar görselleştirildi.

\subsubsection{Tiroid kanseri ile ilgili protein-protein etkileşim (PPI) ağı oluşturulması}

Daha önceden kurulan 21052 protein arasında 288033 fiziksel etkileşim gösteren detaylı insan protein-protein etkileşim ağı (PPI) ağı kullanıldı [19]. Ortak anlatımı değişen genlerin ve birincil komşularıyla zenginleştirilen ortak anlatımı değişen genlerin PPI ağı çizildi. Ağın görselleştirilmesi ve topolojik özelliklerin hesaplanması Cytoscape v3.6 [20] ile yapıldı..

\subsubsection{Biyoişaretçi adayların belirlenmesi}

Ortak anlatımı değişen genlerin ve birincil komşularıyla zenginleştirilen ortak anlatımı değişen genlerin protein etkileşim ağı oluşturulmuştur. Bu etkileşim ağında topolojik olarak ön plana çıkan proteinler belirlenmiştir. Ağdaki diğer proteinlerle etkileşim sayısına bakılarak daha önceki çalışmalarımızda da kullandığımız bir metodla [21] diğer proteinler ile etkileşim sayısı ve bilgi akışı skoru olarak adlandırılan 'degree ve betweennes centrality' değerlerine göre belirlenen proteinler biyoişaretçi aday olarak sunulmuştur.

\subsubsection{Biyoişaretçi aday olma potansiyelinin araştırılması}

Gene ifadesi analizinde kullanılan veri setlerinden bağıms1z olarak seçilen GSE3678 veri seti kullanılarak belirlenen biyoişaretçi adayların tümör ve sağlıklı dokuları birbirinden ayırma potansiyelleri incelenmiştir. Gen ifadesi değerleri ham verilerden alınan biyoişaretçi adayların CIMminer programı ile öklit mesafesine göre 1sı haritası çizdirilmiştir (https://discover.nci.nih.gov/cimminer/home.do).

\section{BULGULAR ve TARTIŞMA}

\subsection{Anlatımı Değişen Genler}

Her bir veri setinin tek tek istatiksel analizi yapılarak anlatımı azalan ve artan genler belirlenmiştir (Şekil 1). Anlatımı değişen gen sayısı en fazla olan veri setinde, GSE35570, 1011 artan, 887 azalan gen tespit edilmiştir. Anlatımı değişen gen saysısı en az olan veri setinde, GSE6004, 139 artan, 197 azalan gen tespit edilmiştir. Diğer 2 veri setinin gen sayıları birbirine yakın bulunmuştur. GSE29265 veri setinde artan 453 gen, azalan 492 gen belirlenirken, GSE3467 veri setinde 414 artan, 433 azalan gen belirlenmiştir. Bütün veri setleri incelendiğinde anlatımı artan ve azalan gen oranlarının her bir veri seti içerisindeki dağılımlarının birbirine yakın olduğu görülmüştür (Şekil 1.A). Ayrıca anlatımı değişen ortak genler de tespit edilmiş ve venn diagram ile bu sonuçlar görselleştirilmiştir. Anlatımı artan 85 gen ve anlatımı azalan 86 gen ortak bulunmuştur. (Şekil 1.B, C) Bu genler dört farklı veri setinin analizi sonucunda bulunduğu için bu gen setleri hastalıkla ilgili güçlü bilgiler verecektir.

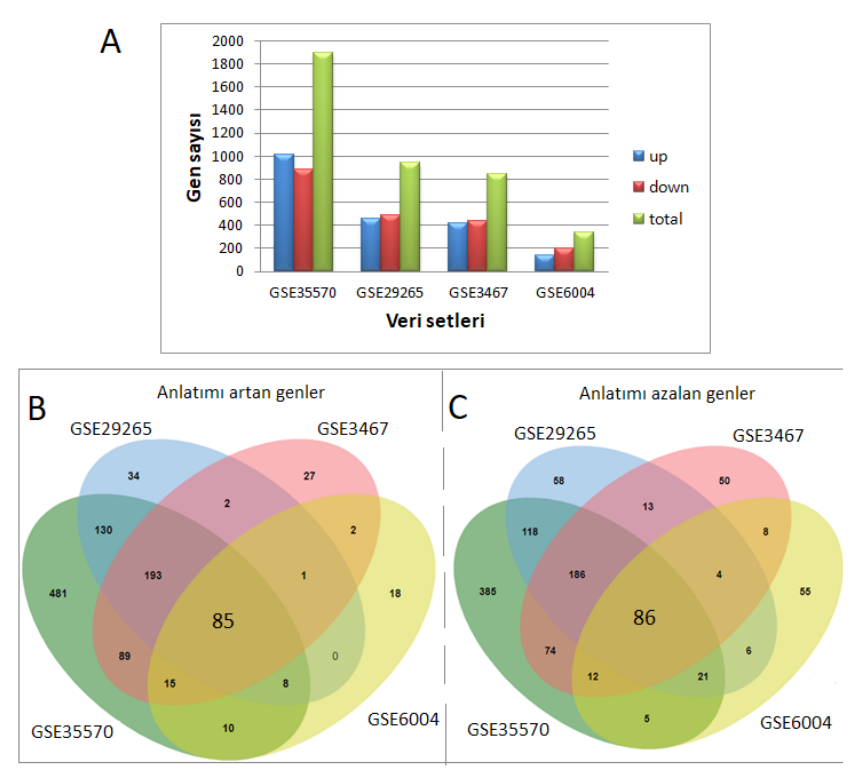

Şekil 1. İstatiksel analizler sonucunda A) anlatımı artan, azalan ve toplam değişen genler, B) anlatımı artan genlerin veri setlerinde dağılımları, C) anlatımı azalan genlerin veri setlerinde dağılımları 


\subsection{Tiroid Kanserinde Aktifleşen Sinyal Yolakları}

Papiller tiroid kanserinde aktifleşen yolakları belirlemek amacıyla DAVID biyoinformatik programı kullanılarak her bir veri setinde anlatımı değişen genlerin rol aldığı yolaklar belirlenmiştir. Anlatımı azalan ve artan genlerin zenginleștirme analizleri ayrı ayrı yapılmış ve sonuçlar 1sı haritası ile görselleştirilmiştir (Şekil 2). Anlatımı artan genlerin zenginleştirme analizleri sonucunda hücrelerin yapışma özellikleri ve reseptör hücre etkileşimi ile ilgili yolaklar ön plana çıkmaktadır. Mesela fokal adezyon, hücre yapışma molekülleri, ECM - reseptör etkileşimi, sitokin sitokin reseptör etkileşim yolakları tiroid kanser dokularında hücreler arasındaki sinyal iletişiminin arttığını göstermektedir. Ayrıca kanserle ilgili yolakların hem azalan hem de artan genlerin zenginleştirme analizlerinde bulunduğu belirlenmiştir. Çünkü hücrede meydana gelen sinyalizasyon olayında görev alan olası proteinlerin miktarı hem artacak hem de azalacaktır. Dolayısıyla bir yolağın proteinlerinin ifadesinin sadece azalması veya sadece artması söz konusu değildir. Isı haritası büyük oranda artan veya azalan proteinlerin analizi sonucunu vermektedir. Kanser yolağı ve kanserde transkripsiyonel yanlış düzenleme yolakları tüm veri setlerinde anlamlı olarak değişmiş ve kanserde mikroRNA'lar yolağının 3 veri setinde anlamlı olarak değiştiği tespit edilmiştir. Bunun yanında kanserle ilişkili önemli sinyal yolaklarının mesela p53 sinyal yolağı, PI3K-Akt sinyal yolağı, TGF-beta sinyal yolağı ve Hippo sinyal yolağının tiroid kanseri zenginleştirme analizlerinde önemli olduğu bulunmuştur. Diğer yolakların bağışıklık sistemi ile ilgili ve metabolizma ilişkili olduğu tespit edilmiştir. Analiz edilen veri setleri kanser örnekleri olması sebebi ile küçük hücreli akciğer kanseri ve pankreas kanseri yolaklarının çıkması şaşırtıcı değildir. Ayrıca viral miyokardit, sıtma, hepatit B gibi hastalıkların sonuçların içerisinde yer alması bu hastalıklarla tiroid kanseri arasında ilişki olabileceği sonucunu sunmaktadır. Anlatımı azalan genlerin zenginleştirme analizi sonuçlarında retinol metabolizması, steroid hormon metabolizması, aminoasit metabolizması gibi çoğunlukla metabolizma ile ilişkili yolakların ön plana çıktığı belirlenmiştir.

Anlatımı değişen ortak genlerin (171 gen) biyolojik olarak anlamlandırılabilmesi için zenginleştirme analizleri yapılmıştır. KEGG biyoinformatik veri tabanı kullanılarak $\mathrm{p}$ değeri 0,05 den küçük olan sonuçlar değerlendirmeye alınmıştır. Anlatımı artan genlerin genellikle kanserde önemli olan yolaklarla ilgili olduğu bulunmuştur. Bu yolaklar p53 sinyal yolağı, kanserde transkripsiyonel yanlış düzenleme, kanser yolağı, PI3K-Akt sinyal yolağı, küçük hücreli akciğer kanseri, hücre yapışma molekülleri ve glioma olarak tespit edilmiştir.
Anlatımı azalan genlerin zenginleştirme analizleri sonuçları ilginç olup enfeksiyon ile ilintili hastalıklarla ilişkili çıkmıştır (Afrikan trypanosomiasis ve sıtma). Gen sayılarının az olduğundan dolayı kanserden farklı hastalıklarla ilişkili sonuç vermiş olabilir ama her bir veri setinin tek tek zenginleştirme analiz sonuçlarında da bu tarz hastalıkların çıkması tiroid kanseri ile aralarında bir ilişki olabileceği sonucunu çıkarmaktadır.

Anlatımı değişen 171 genin zenginleştirme analizleri yapıldığında benzer sonuçlar elde edilmiştir. Bu sonuçlar sitma, Afrikan trypanosomiasis, ksenobiyotiklerin sitokrom P450 ile metabolizması, kanser yolağı, kanserde mikroRNA'lar ve p53 sinyal yolağı olarak belirlenmiştir. Enfeksiyon hastalıklar ve kanser ile ilişkili yolakların aktifleștiğine dikkat çekmektedir.

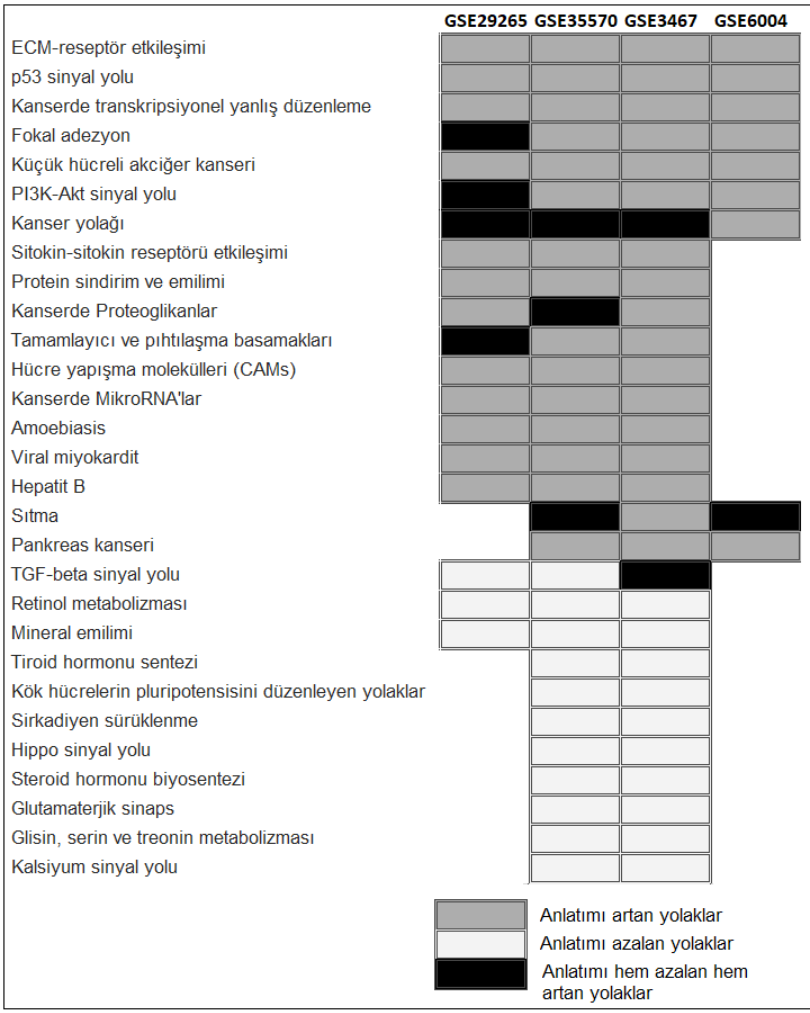

Şekil 2. Zenginleştirme analizi sonuçlarına göre her bir veri seti için anlatımı artan, azalan ve hem artıp hem azalan biyolojik yolaklar

\subsection{Tiroid Kanseri İlintili Protein Etkileşim A}

Metot kısmında belirtilen güvenilir insan protein - protein etkileşim ağ kullanılarak ortak 171 genin protein etkileşim ağı incelendi. Bu proteinler arasında etkileşim sayısı düşük 
çıkmıştır (Şekil 3). NRCAM, ANK2, TNIK arasında iletişim ve JUN ile MAFB arasında iletişim olduğu bulunmuştur.

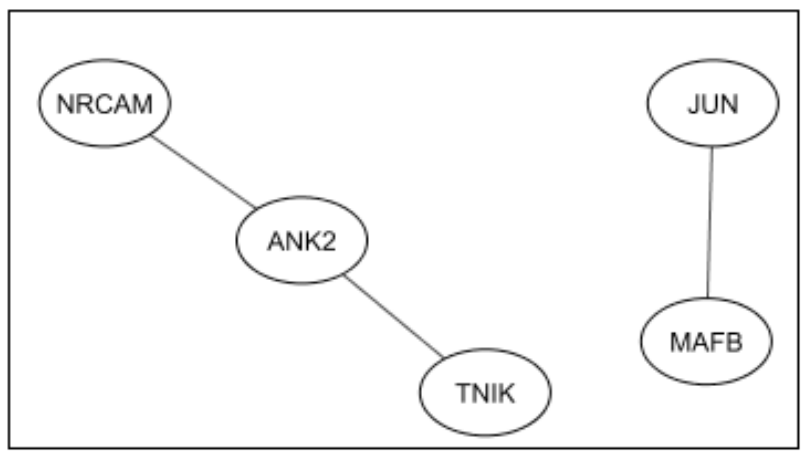

Şekil 3. Anlatımı değişen ortak proteinlerin etkileşim ağı

Protein-protein etkileşim ağları sinyalizasyon ve hücresel proseslerin gerçekleşmesi için önemli işlemlerdir. Bu açıdan geniş ağların olması beklenmektedir. Ortak olan 171 proteinin etkileşimde olduğu ilk proteinler alınarak daha geniş hastalığa özel protein etkileşim ağı oluşturulmuştur (Şekil 4). Bu tiroid kanserine özgü ağda 904 protein ve bu proteinler arasında 1698 etkileşim olduğu tespit edilmiştir.

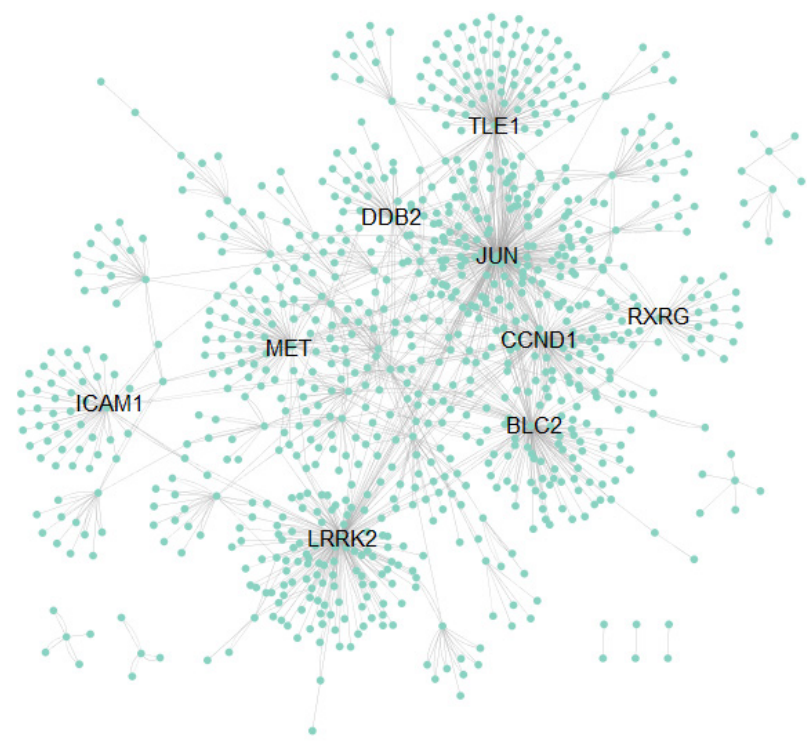

Şekil 4. Tiroid kanserine özel geniş protein protein etkileşim ağ1

$\mathrm{Bu}$ etkileşim ağında çok sayıda proteinle etkileşimde olan hub diye adlandırılan proteinler belirlenmiştir. Ağ Biyotıbbı çalışmalarında hub proteinler belirlenirken genellikle 2 tip metrik kullanılır. Birisi ağdaki diğer proteinlerle etkileşim sayısına bakılarak hesaplanan 'degree centrality', diğeri ise bir proteinin ağdaki bilgi akışı üzerindeki etkisinin miktarının saptanması yani bir bölümünden diğerine köprü görevi gören proteinleri bulmak için kullanılan 'betweennes centrality'dir. Etkileşimi en yüksek olandan aza doğru belirlenen hub proteinler JUN, LRRK2, BCL2, CCND1, TLE1, MET, ICAM1, DDB2 ve RXRG olarak bulunmuştur. Bu proteinlerin tiroid kanserine özgü PPI ağındaki topolojik özellikleri ve biyolojik proses ve yolaklardaki rolleri GeneCards [22] veri tabanı aracılı̆̆ıyla belirlenmiştir (Tablo 2). $\mathrm{Bu}$ proteinlerin genellikle transkripsiyon faktörü oldukları veya transferaz aktivitesine sahip oldukları belirlenmiştir. Rol aldıkları yolaklara bakıldığında 3 tanesinin apoptozla ilişkili yolaklarda bulunduğu ve diğer bir çoğununda kanserle ilişkili mesela MAPK, Wnt, NOTCH1 gibi sinyal iletiminden sorumlu yolaklarda ve protein, hormon metabolizması ile ilgili yolaklarda yer aldıkları belirlenmiştir.

Tablo 2. Hub proteinlerin protein etkileşim ağındaki topolojik özellikleri ve biyolojik rolleri

\begin{tabular}{|c|c|c|c|c|}
\hline & $\begin{array}{l}\text { Diğer } \\
\text { protein- } \\
\text { lerle et- } \\
\text { kileşim } \\
\text { sayısı }\end{array}$ & $\begin{array}{l}\text { Bilgi } \\
\text { akışı } \\
\text { skoru }\end{array}$ & $\begin{array}{l}\text { Gen ontolojisi } \\
\text { açılaması }\end{array}$ & İlişsili yolak \\
\hline JUN & 318 & 0.379 & $\begin{array}{l}\text { Transkripsiyon } \\
\text { faktörü, DNA } \\
\text { ya bağlanma }\end{array}$ & $\begin{array}{l}\text { Apoptoz Modülasyonu } \\
\text { ve Farmakodinamik }\end{array}$ \\
\hline LRRK2 & 210 & 0,264 & $\begin{array}{l}\text { Protein homo- } \\
\text { dimerizasyon } \\
\text { ve transferaz } \\
\text { aktivitesi }\end{array}$ & $\begin{array}{l}\text { MAPK sinyal yolağı ve } \\
\text { Wnt Sinyal Yolağı (plu- } \\
\text { ripotensi ilişkili) }\end{array}$ \\
\hline BCL2 & 151 & 0,163 & $\begin{array}{l}\text { Protein homo- } \\
\text { dimerizasyon } \\
\text { ve özdeş pro- } \\
\text { tein bağlan- } \\
\text { ması }\end{array}$ & $\begin{array}{l}\text { Apoptozis Modülasyon } \\
\text { ve HGF sinyal yolağı }\end{array}$ \\
\hline CCND1 & 149 & 0.148 & $\begin{array}{l}\text { Protein kinaz } \\
\text { aktivitesi ve } \\
\text { enzim bağlan- } \\
\text { mas1 }\end{array}$ & $\begin{array}{l}\text { Glioma ve CDK ara- } \\
\text { c1lı fosforilasyon ve } \\
\text { Cdc6'nın çıkarılması }\end{array}$ \\
\hline TLE1 & 139 & 0.181 & $\begin{array}{l}\text { Özdeş protein } \\
\text { bağlanması ve } \\
\text { transkripsiyon } \\
\text { faktörü bağ- } \\
\text { lanması }\end{array}$ & $\begin{array}{l}\text { NOTCH1 sinyal yo- } \\
\text { lağ1 ve } \\
\text { Notch ve Wnt sinyalle- } \\
\text { rinde Presenilin eylemi }\end{array}$ \\
\hline MET & 82 & 0.109 & $\begin{array}{l}\text { Transferaz ak- } \\
\text { tivitesi ve pro- } \\
\text { tein tirozin ki- } \\
\text { naz aktivitesi }\end{array}$ & $\begin{array}{l}\text { Sinovyal fibroblastlarda } \\
\text { apoptotik yolaklar } \\
\text { ve TCPTP'nin aracılık } \\
\text { ettiği sinyal yolakları }\end{array}$ \\
\hline ICAM1 & 57 & 0.095 & $\begin{array}{l}\text { Hücre içi adez- } \\
\text { yon molekülü, } \\
\text { transmembran } \\
\text { molekülü }\end{array}$ & $\begin{array}{l}\text { Tromboksan A2 resep- } \\
\text { törü sinyali ve İnterlö- } \\
\text { kin-10 sinyal yolağ1 }\end{array}$ \\
\hline
\end{tabular}




\begin{tabular}{|c|c|c|c|c|}
\hline DDB2 & 45 & 0.044 & $\begin{array}{l}\text { Ubiquitin-pro- } \\
\text { tein transferaz } \\
\text { aktivitesi ve } \\
\text { hasarlı DNA } \\
\text { bağlanması }\end{array}$ & $\begin{array}{l}\text { Glioma ve proteinlerin } \\
\text { metabolizmas1 }\end{array}$ \\
\hline RXRG & 45 & 0.043 & $\begin{array}{l}\text { Transkripsi- } \\
\text { yon faktörü ve } \\
\text { RNA polime- } \\
\text { raz II düzenle- } \\
\text { yici bölge di- } \\
\text { zisine özgü } \\
\text { DNA bağlan- } \\
\text { ması }\end{array}$ & $\begin{array}{l}\text { Paratiroid hormon sen- } \\
\text { tezi, sekresyon ve Gli- } \\
\text { oma }\end{array}$ \\
\hline
\end{tabular}

Bağımsız bir veri seti kullanılarak, tümör ile normal dokudaki hub genlerin ifadeleri öklit mesafesi ile hesaplanarak 1Sı haritası olarak çizdirilmiştir (Şekil 5). Tümör ve sağlıklı dokuların 2 ana gruba ayrıldığı belirlenmiş ve bu dokuz genin tümör ve normal tiroid dokularını ayırt edebileceği belirlenmiştir. Söz konusu genlerin biyoişaretçi aday olarak kullanılabileceği sonucuna varılmıştır.

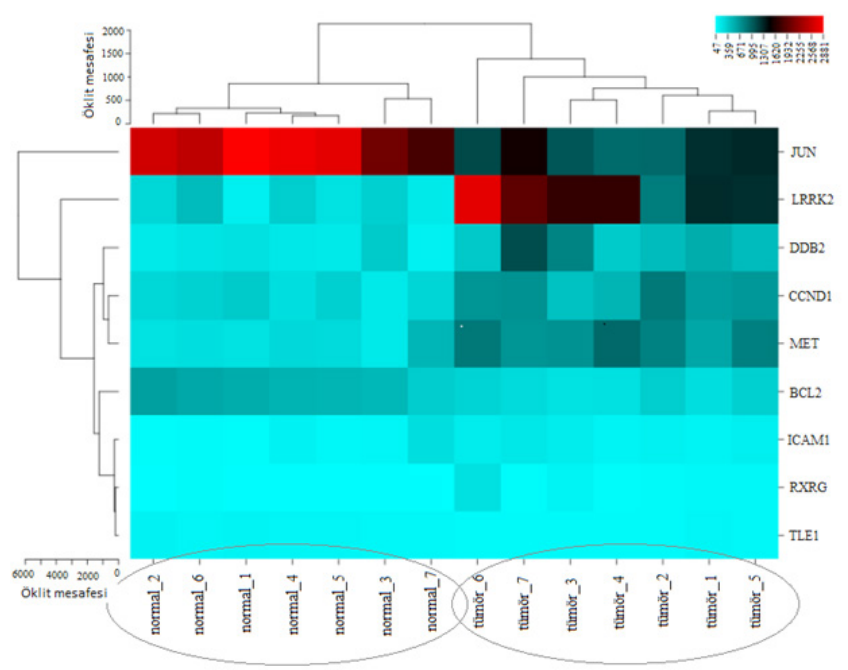

Şekil 5. Biyoişaretçi adayların gen ifadelerinin öklit mesafesine göre kümelenme sonucu

\subsection{Tartışma}

Tiroid kanseri görülme sıklığı yüksek olan ve ölümcül bir kanser türüdür. Tiroid kanseri insidansı özellikle PTK vakaları olarak son birkaç on yılda hızla artmıştır. Özellikle bu insidansın artış nedeni sigara içme ve obezite olarak belirtilmektedir [23]. 2013 Türkiye halk sağlığ1 verilerine göre kadınlarda en sık tanı konulan 2. maliğnitedir [24]. Dolayısiyla tiroid kanserinde etkin rol alan moleküllerin belirlenmesi hastalığın erken tanı ve tedavi stratejilerinin oluşturulması için çok önemlidir.
Sistem biyotıp (systems biomedicine), insanlarda, hayvanlarda ve hücresel modellerde gelişimsel ve patolojik süreçlerin anlaşılması için sistem biyolojisi veri, araç, yöntem, uygulama ve yaklaşımlarının kullanılması olarak tanımlanmaktadır [25]. Farklı seviyelerden hiyerarşik yapıya ait (molekül, organel, hücre, doku, mikroçevre, organ, organizma, çevresel faktörler, popülasyon, ekosistem) verilerin keşfi ve bütünleştirilmesi neticesinde, incelenmekte olan biyolojik süreçlerin bütünsel bir yaklaşım içinde anlaşılmasını hedefler. Bu kapsamda temel araçları hücresel ağlardır (metabolizma ağı, protein-protein etkileşim ağı, gen ekspresyon düzenleme ağı, vb.). Bu çalışmada anlatımı azalan ve artan genler benzer özelliklere sahip örnekleri içeren 4 farklı çalışmanın analizi sonucunda belirlenmiştir. Meta analiz diye adlandırılan veri birleştirilmesi işlemi gerçekleştirilmiştir. Böylelikle daha yüksek populasyon sayısına ulaşılarak istatistiksel testlerin doğruluğu güçlendirilmiştir. İnsan protein-protein etkileşim ağı oluşturmak üzere protein-protein etkileşim bilgileri halka açık çeşitli veri bankalarında sunulmaktadır. Veri bankalarından elde edilen etkileşim verilerinden insan protein-protein etkileşim ağı daha önceden oluşturulmuş ve tip 2 diyabet [26], polikistik over sendromu, endometriyosis [21] ve over kanseri [27] gibi hastalıkların incelenmesinde kullanılmıştır. Bu çalışmada ise veri bankalarında mevcut mRNA ekspresyon verilerinin ileri istatiksel analizleri yapılarak, sonuçlar bütünleştirilmiş ve interaktom (protein-protein etkileşim ağı) oluşturulmuştur. Hastalıkta önemli olabilecek bir takım moleküler hedefler ve biyoişaretçi adaylar belirlenmiştir. Literatürde yapılan diğer çalışmalardan farklı olarak, farklı deneysel çalışmalardan elde edilen yüksek sayıda veri setlerinin bütünleştirilmesi, 100'ün üzerinde hastayı kapsayacak genişlikte bir çalışma olması, farklı doku örneklerini içermesi, insan protein etkileşim ağı ile sonuçların birleştirilmesi ve veri setlerinin sistem biyolojisi bakış açısından bütünleştirilerek değerlendirilmesi açılarından önemlidir.

Bütün veri setleri incelendiğinde anlatımı artan ve azalan gen oranlarının her bir veri seti içerisindeki dağılımlarının birbirine yakın olduğu görülmüştür. Ayrıca her biri veri setinin ayrı ayrı zenginleştirme analizleri sonucu bize hastalıkla aktifleşen ilgili yolaklar hakkında önemli bilgiler verecektir. Anlatımı artan genlerin zenginleştirme analizleri sonucunda tüm veri setlerinde hücrelerin yapışma özellikleri ve aralarındaki sinyal iletimi ile ilgili yolaklar ön plana çıkarken, anlatımı azalan genlerin zenginleştirme analizi sonucunda metabolizma ile ilişkili yolakların ön plana çıktığı belirlenmiştir. Kanser ile ilişkili yolaklar hem azalan hem de artan genlerin zenginleştirme analizi sonucunda çıkmıştır. Önemli sinyal yolakları olan p53 sinyal yolağı, PI3KAkt sinyal yolağı, TGF-beta sinyal yolağı ve Hippo sinyal 
yolağının tiroid kanserinde etkin yolaklar olabileceği bulunmuştur. P53 proteinin ve etkileşimde bulunduğu üyelerinin (p63, p73) tiroid kanserinin gelişmesinde etkin olduğu bilinmektedir [28]. Birçok çalışmada PI3K-Akt sinyal yolağının tiroid kanserinin aktifleşmesinde etkin olduğu rapor edilmiş hatta son zamanlarda bu yolakları düzenleyen miRNA'lar sunulmuştur [29,30]. TGF-beta nın BRAF mutasyonuna sahip tiroid kanserinde epitelyal mezenkimal geçişi (EMT) etkileştirdiği sunulmuştur [31]. Zenginleştirme analizi sonuçlarına göre Afrikan trypanosomiasis, sıtma, hepatit $\mathrm{b}$ ve viral miyokardit gibi hastalıklarla tiroid kanseri arasında ilişki olabileceği söylenebilir ancak literatürde tiroid kanserinin bu hastalıklarla ilişkisine dair çalışmaya rastlanmamıştır. Sadece anti-maleryal bir ilacın tümör hipoksisini azaltarak radyosensitiviteyi arttırdığı rapor edilmiştir [32].

Anlatımı değişen ortak genlerin protein etkileşim ağında NRCAM, ANK2, TNIK arasında iletişim ve JUN ile MAFB arasında iletişim olduğu bulunmuştur. Papillary tiroid kanserinde NrCAM in anlatımının attığı ve diyagnostik biyoişaretçi olabileceği raporlanmıştır. Ayrıca NrCAM anlatımının azaltılması ile farelerde kanser hücrelerinin büyüme, invasiv ve tümorojenik potansiyellerinin azaldığı sunulmuştur [33]. ANK2 sıklıkla anlatımı değişen genler arasında rapor edilmektedir [34]; ancak direkt tiroid kanseri ile ilişkili çalışmaya rastlanmamıştır. Traf2 ve Nck- etkileşime giren protein kinaz (TNIK), $-\beta$ katenin ve T hücre faktörü 4 (TCF-4) transkripsiyon kompleksinin düzenleyici bir bileşeni olarak tanımlanmaktadır. Bu protein kinazı hedef alan bazı küçük moleküllerin çeşitli kanserlere karşı anti-tümör etkileri olduğu gösterilmiştir [35]. Tümörün gelişimi ve devamında AP1 (JUN) transkripsiyon faktörünün önemli rol aldığı belirlenmiştir [36]. MAFB transkripsiyon faktörü olup tiroid kanseriyle ilgili rapor edilmiş bir bilgiye rastlanmamıştır.

Ortak olan 171 proteinin etkileşimde olduğu ilk proteinler alınarak daha geniş tiroid kanserine özel protein etkileşim ağında hub proteinler JUN, LRRK2, BCL2, CCND1, TLE1, MET, ICAM1, DDB2 ve RXRG olarak bulunmuştur. LRRK2'nin PTK dokularında anlatımının arttığı ve kültürdeki tümör hücrelerinde LRRK2'nin anlatımının azaltılması ile MET aktivasyonunun azaldığı ve MET sinyalinin mTOR ve STAT3'e geçişinin azaldığı bildirilmiştir [37]. BLC2 ise anti-apoptotik özelliklere sahip iyi bilinen bir apoptoz düzenleyicisidir. Koreli insanların dokuları alınarak gerçekleştirilen çalışmada BLC2'nin tek nükleotid polimorfizmlerinin (SNP) PTK'de etkin olduğu belirlenmiştir [38]. Benzer şekilde CCND1 geni polimorfizmi Türk insanlarında özellikle daha yaşlı ve/veya kadın olan deneklerde PTK'de belirlenmiştir [39]. TLE ailesi proteinleri, birçok transkripsiyon faktörünün ortak baskılayıcıları olarak görev yapar ve anahtar sinyalizasyon yolaklarına katılırlar. Çalışmalar TLE1'in tanısal bir belirteç olarak kullanılabileceğini ve çeşitli malignitelerde olası bir terapötik hedef olduğunu göstermektedir [40]. Ancak PTK ile ilişkisine dair bir çalışmaya rastlanmamıştır, bu nedenle TLE1 potansiyel yeni biyoişaretçi aday olabilir. MET proto-onkogen ve reseptör tirozin kinazdır; kanser sinyal yolaklarında etkin rol alan bir proteindir. Tiroid tümörlerinde XL184'ün MET'i inhibe etmesiyle ile ilişkili birçok çalışma mevcuttur [41, 42]. Papiller tiroid karsinomunda ICAM-1'in anlatımının artı̆̆ 1 belirlenmiş. Ayrica, ICAM-1' in anlatımının artmas1, BRAF V600E mutasyonu ve lenf nodu metastazı gibi agresif tümör özellikleri ile korele olduğu bulunmuştur. ICAM-1 in tiroid kanserinin ilerlenmesinde etkin olduğu raporlanmıştır [43]. DDB2' nin birçok kanser çeşidinde anlatımının değiştiği belirlenmiş ve malignansi üzerinde düzenleyici etkilerinin olduğu belirlenmiştir; örnek olarak meme kanseri [44], over kanseri [45], mide kanseri [46] ve kolon kanseri [47] veriebilir. Ancak tiroid kanserinde etkinliği ile ilgili çalışmaya rastlanmamıştır, DDB2 yeni biyoişaretçi aday olabilir. RXRG'nin ise PTK örneklerinde anlatımının arttığı eş zamanlı-PCR ile belirlenmiş ve de-diferensiyasyon ve metastazla ilişkili olabileceği rapor edilmiştir [48].

\subsection{Sonuç ve Değerlendirmeler}

PTK'de pek çok mutasyon ve biyoişaretçi aday çalışılmasına rağmen henüz tam anlamılla tanı koydurucu ve tedavi hedefi olabilecek bir belirteç ya da mutasyon bulunamamıştır. Bu çalışmada tiroid dokusuna ait farklı yüksek boyutlu işlevsel genomik verilerin analizi ile elde edilen sonuçlar bütünleştirilmişsir. Zenginleştirme analizleri ile p53, PI3K-Akt, TGF-beta ve Hippo sinyal yolağının tiroid kanserinde etkin yolaklar olabileceği bulunmuştur. Tiroid kanserine özgü protein etkileşim ağı kurularak, JUN, LRRK2, BCL2, CCND1, TLE1, MET, ICAM1, DDB2 ve RXRG hedef moleküller ve biyoişaretçi adaylar olarak belirlenmiştir. Bağımsız bir veri setinden alınan bu genlerin ifadelerinin, tümör ve sağlıklı dokuları ayırabildiği belirlenmiştir. Ayrıca JUN, TLE1 ve DBB2'nin yeni moleküler hedefler ve biyoişaretçi adaylar olabileceği bulunmuştur. Bu moleküler hedeflerin PTK'nin teşhis ve tedavi stratejilerinin oluşturulmasında kullanılabileceği öngörülmektedir. Ancak sözkonusu adayların validasyonu için deneysel çalışmaların yapılması gerekmektedir.

\section{TEŞEKKÜR}

Bu çalışma 17103030 numaralı Adana Alparslan Türkeş Bilim ve Teknoloji Üniversitesi BAP Araştırma projesi kapsamında desteklenmiştir. 


\section{KAYNAKLAR}

[1] Carling, T. \& Udelsman, R. (2005). Thyroid tumors. Annual Review of Medicine, 9, 1457-1472.

[2] Xing, M. (2013). Molecular pathogenesis and mechanisms of thyroid cancer. Nature Reviews Cancer, 13(3), 184.

[3] Elisei, R., Ugolini, C., Viola, D., Lupi, C., Biagini, A., Giannini, R., Romei, C., Miccoli, P., Pinchera, A. \& Basolo, F. (2008). BRAF(V600E) mutation and outcome of patients with papillary thyroid carcinoma: a 15-year median follow-up study. The Journal of Clinical Endocrinology \& Metabolism, 93, 3943-3949.

[4] Yip, L., Nikiforova, M.N., Carty, S.E., Yim, J.H., Stang, M.T., Tublin, M.J., Lebeau, S.O., Hodak, S.P., Ogilvie, J.B. \& Nikiforov Y.E. (2009). Optimizing surgical treatment of papillary thyroid carcinoma associated with BRAF mutation. Surgery, 146,1215-1223.

[5] Handkiewicz-Junak, D., Swierniak, M., Rusinek, D., Oczko-Wojciechowska, M., Dom, G., Maenhaut, C., Unger, K., Detours V., Bogdanova, T.,Thomas, G.,Likhtarov, I., Jaksik, R.,Kowalska, M., Chmielik, E., Jarzab, M., \& Swierniak A. (2016). Gene signature of the post-Chernobyl papillary thyroid cancer. European journal of nuclear medicine and molecular imaging, 43(7), 1267-1277.

[6] Chien, M. N., Yang, P. S., Lee, J. J., Wang, T. Y., Hsu, Y. C. \& Cheng, S. P. (2017). Recurrence-associated genes in papillary thyroid cancer: An analysis of data from The Cancer Genome Atlas. Surgery, 161(6), 1642-1650.

[7] Vasko, V., Espinosa, A. V., Scouten, W., He, H., Auer, H., Liyanarachchi, S., Larin, A., Savchenko, V., Francis, G. L. de la Chapelle, A., Saji, M. \& Ringel M.D. (2007). Gene expression and functional evidence of epithelial-to-mesenchymal transition in papillary thyroid carcinoma invasion. Proceedings of the National Academy of Sciences, 104(8), 2803-2808.

[8] Burniat, A., Jin, L., Detours, V., Driessens, N., Goffard, J. C., Santoro, M., Rothstein, J. Dumont, J. E., Miot F. \& Corvilain, B. (2008). Gene expression in RET/PTC3 and E7 transgenic mouse thyroids: RET/PTC3 but not E7 tumors are partial and transient models of human papillary thyroid cancers. Endocrinology, 149(10), 5107-5117.

[9] McFadden, D. G., Vernon, A., Santiago, P. M., Martinez-McFaline, R., Bhutkar, A., Crowley, D. M., McMahon, M., Sadow P. M. \& Jacks, T. (2014). p53 constrains progression to anaplastic thyroid carcinoma in a Braf-mutant mouse model of papillary thyroid cancer. Proceedings of the National Academy of Sciences, 111(16), E1600-E1609.

[10] Zhao, H. \& Li, H. (2018). Network-based meta-analysis in the identification of biomarkers for papillary thyroid cancer. Gene, 661, 160-168.

[11] Yu, J., Mai, W., Cui, Y. \& Kong, L. (2016). Key genes and pathways predicted in papillary thyroid carcinoma based on bioinformatics analysis. Journal of endocrinological investigation, 39(11), 1285-1293.
[12] Shang, J., Ding, Q., Yuan, S., Liu, J.X., Li, F. \& Zhang, H. (2019). Network Analyses of Integrated Differentially Expressed Genes in Papillary Thyroid Carcinoma to Identify Characteristic Genes. Genes, 10 (11), 45.

[13] Barrett, T., Troup, D.B., Wilhite, S.E., Ledoux, P., Evangelista, C., Kim, I .F., Tomashevsky, M., Marshall, K.A., Phillippy, K.H., Sherman, P.M., Muertter, R.N., Holko, M., Ayanbule, O., Yefanov, A. \& Soboleva, A. (2011). NCBI GEO: archive for functional genomics data sets-10 years on, $\mathrm{Nuc}$ leic Acids Research, 39(Database issue): D1005-D1010.

[14] Handkiewicz-Junak, D., Swierniak, M., Rusinek, D., Oczko-Wojciechowska, M., Dom, G., Maenhaut, C., Unger, K., Detours, V., Bogdanova, T., Thomas, G., Likhtarov, I., Jaksik, R Kowalska, M., Chmielik, E., Jarzab, M., Swierniak, A. \& Jarzab, B. (2016). Gene signature of the post-Chernobyl papillary thyroid cancer. European journal of nuclear medicine and molecular imaging, 43(7), 1267-1277.

[15] He, H., Jazdzewski, K., Li, W., Liyanarachchi, S., Nagy, R., Volinia, S., \& Kloos, R. T. (2005). The role of microRNA genes in papillary thyroid carcinoma. Proceedings of the National Academy of Sciences, 102(52), 19075-19080.

[16] Vasko, V., Espinosa, A. V., Scouten, W., He, H., Auer, H., Liyanarachchi, S., Larin, A., Savchenko, V., Francis, G. L., Chapelle, A., Saji, M. \& Ringel, M.D. (2007). Gene expression and functional evidence of epithelial-to-mesenchymal transition in papillary thyroid carcinoma invasion. Proceedings of the National Academy of Sciences, 104(8), 28032808.

[17] Smyth G.K. (2005). Limma: linear models for microarray data. In: Bioinformatics and Computational Biology Solutions using R and Bioconductor, R. Gentleman, V. Carey, S. Dudoit, R. Irizarry, W. Huber (eds.), Springer, New York, 397-420.

[18] Huang D.W., Sherman, B.T., Tan, Q., Kir, J., Liu, D., Bryant, D., Guo, Y., Stephens, R., Baseler, M. W., Lane, H. C. \& Lempicki, R.A. (2007). DAVID Bioinformatics Resources: expanded annotation database and novel algorithms to better extract biology from large gene lists, Nucleic Acids Research, 35(Web Server issue), W169-W175.

[19] Karagoz, K., Sevimoglu, T. \& Arga, K. Y. (2016). Integration of multiple biological features yields high confidence human protein interactome. Journal of theoretical biology, 403, 8596.

[20] Shannon, P., Markiel, A., Ozier, O., Baliga, N.S., Wang, J.T., Ramage, D., Amin, N., Schwikowski, B. \& Ideker, T. (2003). Cytoscape: a software environment for integrated models of biomolecular interaction networks, Genome Research, 13(11), 2498-504.

[21] Kori, M., Gov, E. \& Arga, K. Y. (2016). Molecular signatures of ovarian diseases: Insights from network medicine perspective. Systems biology in reproductive medicine, 62(4), 266282. 
[22] Stelzer, G., Rosen, R., Plaschkes, I., Zimmerman, S., Twik, M., Fishilevich, S., Iny Stein, T., Nudel, R., Lieder, I., Mazor, Y., Kaplan, S., Dahary, D., Warshawsky, D., Guan - Golan, Y., Kohn, A., Rappaport, N., Safran, M., \& Lancet D. (2016), The GeneCards Suite: From Gene Data Mining to Disease Genome Sequence Analysis, Current Protocols in Bioinformatics, 54, 1.30.1.

[23] Kitahara, C. M. \& Sosa, J. A. (2016). The changing incidence of thyroid cancer. Nature Reviews Endocrinology, 12(11), 646.

[24] TC Sağlık Bakanlığı, Türkiye Halk Sağlığı Kurumu, Kanser istatistikleri, (2016).

[25] Liu, E. T. (2010). Foundations for Systems Biomedicine: an Introduction. In Systems Biomedicine Academic Press, Singapur. 1-13

[26] Calimlioglu, B., Karagoz, K., Sevimoglu, T., Kilic, E., Gov, E. \& Arga, K. Y. (2015). Tissue-specific molecular biomarker signatures of type 2 diabetes: an integrative analysis of transcriptomics and protein-protein interaction data. Omics: a journal of integrative biology, 19(9), 563-573.

[27] Gov, E., Kori, M. \& Arga, K. Y. (2017). Multiomics analysis of tumor microenvironment reveals Gata2 and miRNA-124-3p as potential novel biomarkers in ovarian cancer. Omics: a journal of integrative biology, 21(10), 603-615.

[28] Manzella, L., Stella, S., Pennisi, M., Tirrò, E., Massimino, M., Romano, C., \& Vigneri, P. (2017). New insights in thyroid cancer and $\mathrm{p} 53$ family proteins. International journal of molecular sciences, 18(6), 1325.

[29] Ramírez-Moya, J., Wert-Lamas, L. \& Santisteban, P. (2018). MicroRNA-146b promotes PI3K/AKT pathway hyperactivation and thyroid cancer progression by targeting PTEN. Oncogene, 37(25), 3369.

[30] Zhao, J., Li, Z., Chen, Y., Zhang, S., Guo, L., Gao, B. \& Zhang, X. (2019). MicroRNA 766 inhibits papillary thyroid cancer progression by directly targeting insulin receptor substrate 2 and regulating the PI3K/Akt pathway. International journal of oncology, 54(1), 315-325.

[31] Knauf, J. A., Sartor, M. A., Medvedovic, M., Lundsmith, E., Ryder, M., Salzano, M. \& Fagin, J. A. (2011). Progression of BRAF-induced thyroid cancer is associated with epithelialmesenchymal transition requiring concomitant MAP kinase and TGF $\beta$ signaling. Oncogene, 30(28), 3153.

[32] Ashton, T. M., Fokas, E., Kunz-Schughart, L. A., Folkes, L. K., Anbalagan, S., Huether, M. \& Stratford, M. (2016). The anti-malarial atovaquone increases radiosensitivity by alleviating tumour hypoxia. Nature communications, 7, 12308.

[33] Zhang, Y., Sui, F., Ma, J., Ren, X., Guan, H., Yang, Q. \& Hou, P. (2016). Positive feedback loops between NrCAM and major signaling pathways contribute to thyroid tumorigenesis. The Journal of Clinical Endocrinology \& Metabolism, 102(2), 613-624.

[34] Liang, W. \& Sun, F. (2018). Identification of key genes of papillary thyroid cancer using integrated bioinformatics analysis. Journal of endocrinological investigation, 41(10), 1237-1245.

[35] Yamada, T. \& Masuda, M. (2017). Emergence of TNIK inhibitors in cancer therapeutics. Cancer science, 108(5), 818823.

[36] Lopez-Bergami, P., Lau, E. \& Ronai, Z. E. (2010). Emerging roles of ATF2 and the dynamic AP1 network in cancer. $\mathrm{Na}$ ture Reviews Cancer, 10(1), 65.

[37] Looyenga, B. D., Furge, K. A., Dykema, K. J., Koeman, J., Swiatek, P. J., Giordano, T. J. \& MacKeigan, J. P. (2011). Chromosomal amplification of leucine-rich repeat kinase-2 (LRRK2) is required for oncogenic MET signaling in papillary renal and thyroid carcinomas. Proceedings of the National Academy of Sciences, 108(4), 1439-1444.

[38] Eun, Y. G., Hong, I. K., Kim, S. K., Park, H. K., Kwon, S., Chung, D. H. \& Kwon, K. H. (2011). A polymorphism (rs1801018, Thr7Thr) of BCL2 is associated with papillary thyroid cancer in Korean population. Clinical and experimental otorhinolaryngology, 4(3), 149.

[39] Aytekin, T., Aytekin, A., Maralcan, G., Gokalp, M. A., Ozen, D., Borazan, E. \& Yilmaz, L. (2014). A cyclin D1 (CCND1) gene polymorphism contributes to susceptibility to papillary thyroid cancer in the Turkish population. Asian Pac. J. Cancer Prev, 15, 7181-7185.

[40] Da Yuan, X. Y., Yuan, Z., Zhao, Y. \& Guo, J. (2017). TLE1 function and therapeutic potential in cancer. Oncotarget, 8(9), 15971.

[41] Salgia, R., Sherman, S., Hong, D. S., Ng, C. S., Frye, J., Janisch, L. \& Kurzrock, R. (2008). A phase I study of XL184, a RET, VEGFR2, and MET kinase inhibitor, in patients (pts) with advanced malignancies, including pts with medullary thyroid cancer (MTC). Journal of Clinical Oncology, 26(15_ suppl), 3522-3522.

[42] Bentzien, F., Zuzow, M., Heald, N., Gibson, A., Shi, Y., Goon, L. \& Zhao, L. (2013). In vitro and in vivo activity of cabozantinib (XL184), an inhibitor of RET, MET, and VEGFR2, in a model of medullary thyroid cancer. Thyroid, 23(12), 1569-1577.

[43] Buitrago, D., Keutgen, X. M., Crowley, M., Filicori, F., A1dailami, H., Hoda, R. \& Fahey, T. J. (2012). Intercellular adhesion molecule-1 (ICAM-1) is upregulated in aggressive papillary thyroid carcinoma. Annals of surgical oncology, 19(3), 973-980.

[44] Ennen, M., Klotz, R., Touche, N., Pinel, S., Barbieux, C., Besancenot, V. \& Domenjoud, L. (2013). DDB2: a novel regulator of NF- $\mathrm{kB}$ and breast tumor invasion. Cancer research, 73(16), 5040-5052.

[45] Han, C., Zhao, R., Liu, X., Srivastava, A., Gong, L., Mao, H. \& Wang, Q. E. (2014). DDB2 suppresses tumorigenicity by limiting the cancer stem cell population in ovarian cancer. Molecular Cancer Research, 12(5), 784-794.

[46] Qiao, S., Guo, W., Liao, L., Wang, L., Wang, Z., Zhang, R. \& Chen, Y. (2015). DDB2 is involved in ubiquitination and degradation of PAQR3 and regulates tumorigenesis of gastric cancer cells. Biochemical Journal, 469(3), 469-480. 
[47] Huang, S., Fantini, D., Merrill, B. J., Bagchi, S., Guzman, G. \& Raychaudhuri, P. (2017). DDB2 is a novel regulator of Wnt signaling in colon cancer. Cancer research, 77(23), 6562-6575.
[48] Liu, Z., Zhou, G., Nakamura, M., Bai, Y., Li, Y., Ozaki, T. $\&$ Kakudo, K. (2011). Retinoid X receptor $\gamma$ up-regulation is correlated with dedifferentiation of tumor cells and lymph node metastasis in papillary thyroid carcinoma. Pathology international, 61(3), 109-115. 